\title{
HIGHER EDUCATION IN THE REPUBLIC OF KAZAKHSTAN: PROBLEMS AND IMPROVEMENT METHODS
}

Ulukbek Aliyev $^{1}$, Nurlan Kurmanov ${ }^{2}$

\begin{abstract}
The paper investigated the current state of higher (business) education in the Republic of Kazakhstan. The research methodology is based on the processing of secondary data, which allows a preliminary analysis of the problems of the education system. The authors give an estimate of the current system of business education in Kazakhstan. The authors conclude that the education system of Kazakhstan is currently under development, competitiveness of the economy largely depends on the quality of education and further growth is impossible without well-educated and trained personnel.
\end{abstract}

UDC Classification: 330.34 (574), DOI: http://dx.doi.org/10.12955/cbup.v3.595

Keywords: educational strategies; control; business education; quality management; business school; development strategy; the Republic of Kazakhstan.

\section{Introduction}

Business education in Kazakhstan is rapidly expanding. The formation of this new market sector involves thousands of people and hundreds of organizations across the country. Almost every manager eventually begins to consider how and where they can improve their business skills. Company executives are also aware of the direct relationship between their own competitiveness and the level of staff training provided, with increases in the proportion of funds being allocated to corporate training in the organization (Turekulova et al., 2013, Kurmanov et al. 2013).

The development of business education in Kazakhstan requires a strategy that involves high quality training for business professionals to meet the demands of the modern economy (Turekulova et al., 2013, Kurmanov et al. 2013).

The existing research on the implementation of business education is theoretical, or only deals briefly with certain aspects of the development of business education. It fails to connect the theoretical and methodological principles with the real issues involved in the construction and development of a business education strategy in Kazakhstan. Therefore, the study subject requires special investigation (Turekulova et al., 2013, Kurmanov et al. 2013).

\section{Literature review}

The works of the following authors were devoted to the study of the theoretical aspects of effective management systems in educational organizations: Datar (2011), Etzkowitz (2004), Bennis \& O’Toole (2005), David \& David (2010), Ghoshal, Arnzen, \& Brownfield (1992), Mintzberg \& Gosling, 2002), Ahrweiler, Pyka, \& Gilbert (2011), Boyatzis (2008), and Schmidt (2008), as well as a few Kazakh authors, such as Kirichok (2013), Rumyantseva (2004), Zhuplev \& Kozhakhtnetov (1997), Kurmanov et al., (2013) and Kurmanov, Zhumanova, \& Kirichock (2013), who also contributed substantially to the development of educational strategies.

Despite the high scientific interest in this problem and the number of studies available, it is worth noting that the issues of business education are neither elaborated upon nor popular when developing strategies today. These considerations have determined the choice of research topics and their direction in this study (Turekulova et al., 2013, Kurmanov et al. 2013).

\footnotetext{
${ }^{1}$ Ulukbek Aliyev, PhD student, Academy of Public Administration under the President of the Republic of Kazakhstan, Republic of Kazakhstan, aliyev0901@gmail.com

2 Nurlan Kurmanov, PhD, Kazakh University of Economics, Finance and International Trade, Republic of Kazakhstan, n.a.kurman@mail.ru
} 
The aim of this paper is to study the scope of business education and the development strategies for the expansion of business education in Kazakhstan (Turekulova et al., 2013, Kurmanov et al. 2013).

\section{Methodology}

We used the SWOT and PEST analyses for strategic analysis of certain components. We also used the model of nine-factor strategic management, which was introduced by Matthews (2003) and then aligned to the requirements of ISO-9000. The use of this model in the evaluation of the innovative potential of a business school offers the following features and results:

- Identification of the current position of the business school, using a broad spectrum of criteria;

- Introduction of new estimates for criteria, associated with the analysis of the business school's internal and external environment, and consumers;

- Detailed revision of the criteria, sub-criteria and indicators of the model to allow a concrete and substantial analysis;

- Assessment of the advanced levels allows us to determine the prospects for further development, making a natural and easy transition from the definition and formulation of problems to the objectives of the business school (Turekulova et al., 2013, Kurmanov et al. 2013).

\section{Current state of education in Kazakhstan}

According to 2010-11 data from Kazakhstan's Agency of Statistics, 149 universities (including 9 public, 13 non-civil, and 96 private) had a role in educating more than 620 million people (excluding master's and doctoral students). This included 310,100 students in the public higher-education establishments and 310,300 in the private higher-education institutions (Turekulova et al., 2013, Kurmanov et al. 2013, The Agency of Statistics of the RK, 2013).

Post-graduate student enrolments increased from 2,469 people in 1991 (Michailova \& Liuhto, 2001) to the highest number of 5,943 in 2003, before decreasing to 20 in 2010 after the abolishment of this education level (Mukhamedzhanov \& Abdirayymova, 2011).

The number of master's students increased from 5,410 people in 2001 to 16,586 in 2010, while the number of students with doctoral degree increased from 30 in 1991 to 960 in 2010 (with reference to a new stage of PhD) (Turekulova et al., 2013, Kurmanov et al. 2013).

According to the Ministry of Education of the Republic of Kazakhstan, there are 16 universities that offer $\mathrm{PhD}$ degrees in partnership with leading foreign universities (Turekulova et al., 2013, Kurmanov et al. 2013).

Starting from 2008, the Kazakhstan national universities began offering positions to foreign professors. For instance, Kazakh National University, named after Al-Farabi, offered 83 positions in 2008, 86 in 2009, and 106 in 2010, to foreign teachers; while the Eurasian National University, named after L.N. Gumilev, offered 55, 83, and 94 positions to foreign professors in those same years, respectively (Kirichok, 2013).

The international model for accreditation of universities, which includes institutional and specialized (professional) accreditation, had been implemented (Turekulova et al., 2013, Kurmanov et al. 2013).

According to the Ministry of Education of the Republic of Kazakhstan, currently five public universities of our country are on the transitional stage of internationally accredited procedures for educational programs. Two of those universities are Kazakh National University, named after Al Farabi, and Kazakh National Technical University, named after K. Satpaev. The former had been 
accredited for 10 educational programs in undergraduate and graduate studies at the German accreditation agency of ASIIN, and the later by the Accreditation Center of the Association for Engineering Education of Russia (RAEE), the German accreditation agency of ASIIN for 5 programs in undergraduate studies, and the ABET agency for one major program (Turekulova et al., 2013, Kurmanov et al. 2013).

\section{Analysis of the Kazakh model of business education: strengths and weaknesses}

Let us consider the domestic factors that shape the national features of business education.

Certainly, the demand for business education will grow. However, the development of business education is undermined by a number of factors:

- Institutional uncertainty. It was only in 2010 that the status of a professionally oriented master's program was defined in legislation, allowing the start of a full-scale development of the national analogue for a Master of Business Administration (MBA) program.

- Lack of full-scale joint educational projects with leading international business schools. Consequently, all training programs are focused exclusively on the domestic market and have yet to be internationally recognized.

- National formats for the master's programs in business education or a second higher-education qualification in economics are deeply integrated into the academic system of higher education. This is regulated by many provisions and policies of the Ministry of Education, which bear the general and non-specific segment of this educational activity, and are often in direct conflict with the current requirements of the market for managerial work.

For example, existing regulations surrounding education make it almost impossible to move onto the credit-modular system in the educational process and use the full-scale of the distance learning technologies.

- Failure to choose targeted audience. Generally, the business schools accept anybody who is able to pay, whereas in Western practice, MBA students are typically tested and selected based on their qualifications (Turekulova et al., 2013, Kurmanov et al. 2013).

- Lack of stable system of effective investment in educational projects.

Also there are following shortcomings in the Kazakh model of business education:

- Lack of MBA programs at the National Universities;

- Lack of studies of the business education in the country;

- Lack of strategy of the business education in Kazakhstan;

$\bullet$

- Lack of qualified professors, practitioners and educators able to teach in Kazakh and English languages;

- Lack of internationalization of the faculty (our professors do not teach abroad);

- Lack of international mobility of students (both Kazakh and foreign);

- Lack of career centers at the business schools for MBA graduates;

- Business education is not considered as an infrastructure element of business;

- Lack of state standards for business programs (MBA, DBA);

- Programs lack the practical component - no case studies for Kazakhstan; 
- High concentration of the business schools (80\% of MBA programs are held in Almaty)

- Opacity of the business education statistics;

- High rates for student loans in the banks;

- Lack of professional associations of the business schools (Turekulova et al., 2013, Kurmanov et al. 2013, Rumyantseva, 2004).

We have developed guidelines for the assessment of the innovative potential of business schools, based on the use of the PEST-analysis and SWOT-analysis techniques (Table 1), as well as the application of a strategic matrix (Table 2).

\begin{tabular}{|c|c|}
\hline Strengths & Weaknesses \\
\hline 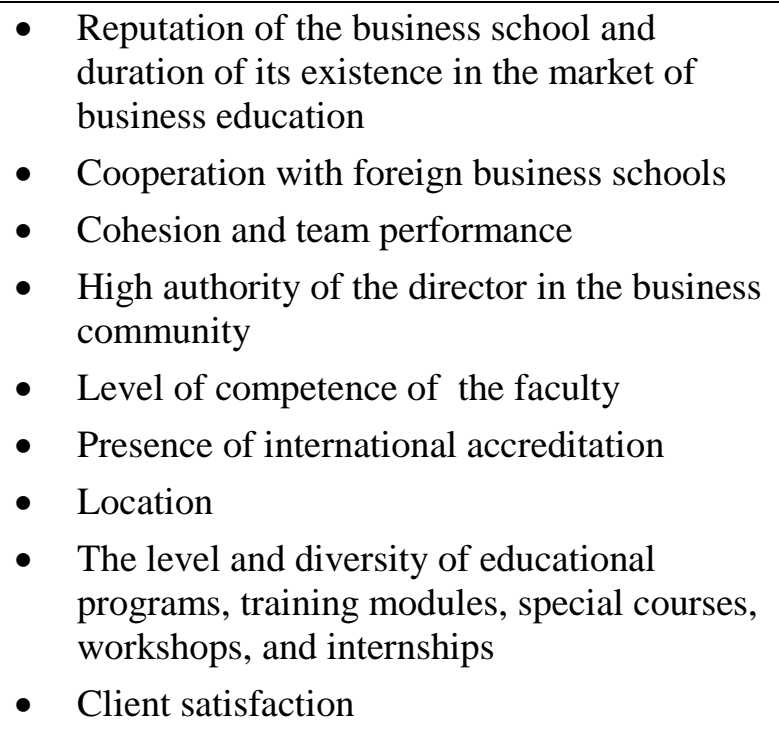 & $\begin{array}{l}\text { - Poor integration between the business } \\
\text { community and the business school } \\
\text { - Inadequate operations, based on } \\
\text { predictions of the labor market } \\
\text { - Passive attraction of teaching } \\
\text { practitioners } \\
\text { - Limited financial resources } \\
\text { - Slow updating of training and technical } \\
\text { bases } \\
\text { - Poor infrastructure of the business } \\
\text { - } \text { Internool }\end{array}$ \\
\hline Opportunities & Threats \\
\hline $\begin{array}{l}\text { - } \begin{array}{l}\text { Growth of the real demand for qualitative } \\
\text { educational services }\end{array} \\
\text { - International co-operation with leading } \\
\text { international business schools } \\
\text { - } \quad \text { Possibilities of multi-channel financing } \\
\text { - Informatization of educational technologies } \\
\text { - Participation in national and international } \\
\text { - } \text { projects } \\
\text { Good partnerships with the Kazakh business }\end{array}$ & $\begin{array}{l}\text { - "Law on Education in the Republic of } \\
\text { Kazakhstan" amendments came into } \\
\text { effect and the prospects for the } \\
\text { adoption of its new edition exclude all } \\
\text { levels of additional business education } \\
\text { from state control: state quality } \\
\text { standards, accreditation procedures and } \\
\text { the issuance of a state diploma program } \\
\text { at all levels are to be cancelled } \\
\text { - Unfavorable demographic trends } \\
\text { - Reduction in the quality of higher } \\
\text { education } \\
\text { - Increased competition in the market of } \\
\text { educational services due to the planned } \\
\text { accession of Kazakhstan to the World } \\
\text { Trade Organization (WTO) } \\
\text { - No line replacement of faculty staff } \\
\text { (due to natural aging, or decline, etc.) }\end{array}$ \\
\hline
\end{tabular}


In this study, we have formulated three main conditions that determine the success of the modernization of Kazakhstan's model of business education:

- Firstly, to generate a high level of education consumption in the country, it is a must to have high-quality educational products and services, including professors and educational technologies that relate to the specifics of business in our country. The gap between the quality of education and the real-world practice is a major obstacle in the development of business education as an infrastructural element of an innovative economy;

- Secondly, there is a necessity in forming a demand for educational services, both on the part of the companies, and on the part of individuals. Heterogeneity of listeners, based on professional potential, motivational structure, and career plans, creates the demand for a differentiated approach towards the formation of educational programs; and

- Thirdly, there are the prospects for adopting a new law "On Education", which excludes, from the scope, the state controlled programs of additional education. There is a need for a public organization that would assimilate a number of regulatory functions of educational activities, including, for instance, public and professional accreditation and certification programs of business education (Turekulova et al., 2013, Kurmanov et al. 2013, The Ministry of Education and Science of the Republic of Kazakhstan, 2010).

The main distinctive features of the Kazakh model of business education are:

- A high degree of concentration of business schools in large cities (Almaty, Astana);

- The specific character of the social composition of the students of business schools being that they are mostly people with a technical education and "technocratic" thinking;

- A lack of qualified professors with practical experience in real business; and

- The limited financial capacity of business schools, etc. (Turekulova et al., 2013, Kurmanov et al. 2013)

Thus, the modernization of the Kazakhstan's system of business education should be implemented in ways that form active use and development of the innovative capacity of educational institutions. This will not only expand the market of educational services, but it will also integrate successfully into the world's and European's educational systems (Piven \& Pak, 2006).

\section{Development strategy of business education}

As a result of the SWOT-analysis, the strengths and weaknesses of the business education in Kazakhstan, along with the opportunities and threats to the development of key strategic directions of the business schools, were identified. The results determined the long-term course of business education development, namely:

- Innovation and educational activities;

- Scientific and innovative activity;

- The development of the resource potential of the business school; and

- Social responsibility and social development (Turekulova et al., 2013, Kurmanov et al. 2013).

The management and staff of business schools must strive to achieve the main goal, which is to create an innovative business school that provides the graduates of managerial classes with qualifications that meet international requirements (Turekulova et al., 2013, Kurmanov et al. 2013).

This study identified the educational objectives for the business processes that involve the basic business functions at the management level, and the targets and indicators within the educational 
business process at a university or business school. This was performed according to the expectations and demands of consumers (students) and educational services in the field of business education, and is schematically demonstrated in Figure 1, as follows (Turekulova et al., 2013, Kurmanov et al. 2013):

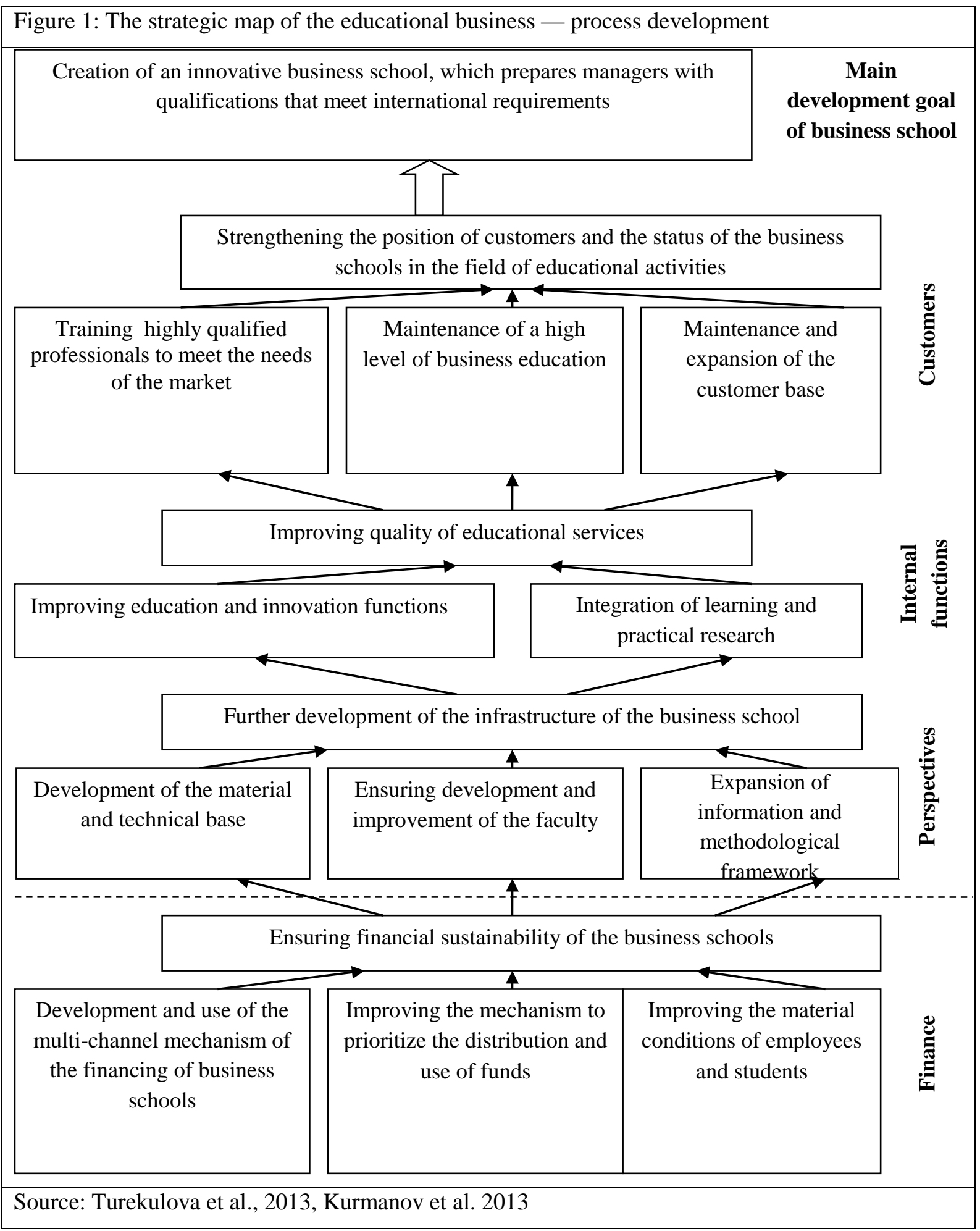

In Table 2 we have proposed strategic indicators of the educational business process as considered in terms of the external efficiency of the business school, and estimated by the quality of students in the programs. 
CBU I NTERNATI ONAL CONFERENCE ON I NNOVATION, TECHNOLOGY TRANSFER AND EDUCATION

March 25-27, 2015, Prague, CZECH RePubliC

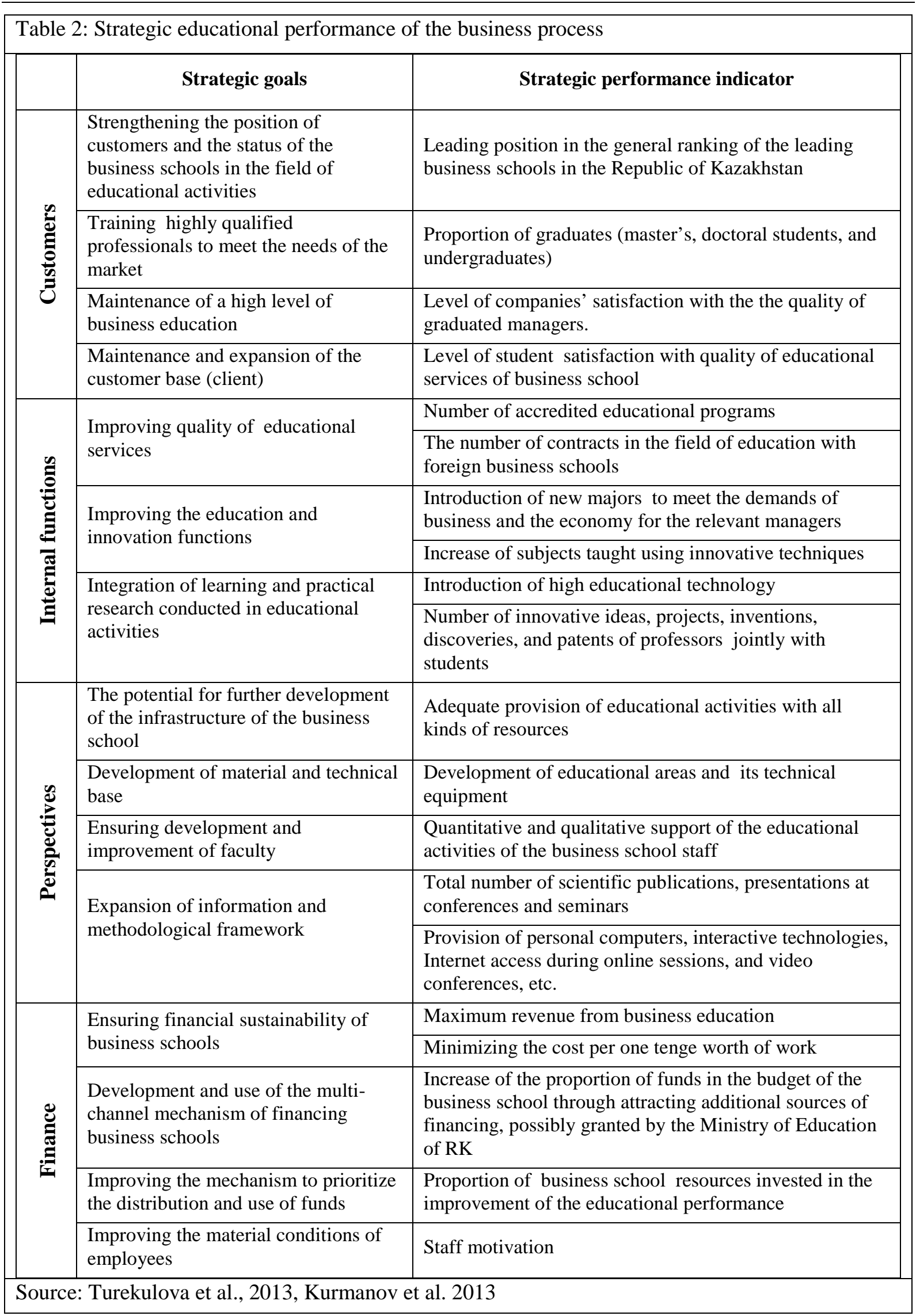




\section{Conclusion}

In today's world, a country's competitiveness is determined by the level of intelligence of its citizens, so the education system must be developed to meet the needs of tomorrow. A new stage of Kazakhstan's development is focused on the rapid progress of the state in the community of 30 most competitive countries of the world. In this sense, the educated youth is a guarantee of development of Kazakhstan, as well as a major resource that can complete the task before the country to join the Republic in 2050 in the number of cherished most developed countries in the world.

In this regard, education policy aimed at creating a national model of education that is integrated into the world educational space and providing training and competitive in the global labor market.

\section{References}

Ahrweiler, P., Pyka, A., \& Gilbert, N. (2011). A new model for University-Industry Links in Knowledge-Based Economies. Journal of Product Innovation management, 28, 218-235.

Bennis, W., \& O’Toole, J. (2005). How business schools lost their way. Harvard Business Review, 134(5), 96-104.

Boyatzis, R. (2008). Competences of the 21st century. Journal of Management Development, 27(1), 67-78.

Datar, S. M., Garvin, D. A., \& Cullen, P. G. (2011). Rethinking the MBA: business education at a crossroads. Journal of Management Development, 30(5), 451-462.

David, F. R., \& David, F. R. (2010). Are business student learning what employers need. Retrieved from http://checkmateplan.com/Are\%20Students.pdf

Etzkowitz, H. (2004). The evolution of the entrepreneurial university. International Journal of Technology and Globalization, 1(1), 64-77.

Ghoshal S., Arnzen B., \& Brownfield S. (1992). A learning alliance between business and Business Schools: Executive education as a platform for partnership. California Management Review, 34(6), 100-112.

Kirichok, O. (2013). Business-education Partnerships as Basis for Effective Socioeconomic Development: Lessons for Kazakhstan. Procedia-Social and Behavioral Sciences, 92, 452-456.

Kirichok, O. (2013). Business and Academia in Kazakhstan: living a cat and dog life? On reconstruction of education policy in Kazakhstan. Life Science Journal, 10(12s), 732-737.

Kurmanov, N. A., Zhumanova, B. K., \& Kirichok, O. V. (2013). Business-Education in Kazakhstan: Opportunities and Development Strategy. World Applied Sciences Journal, 21(10), 1495-1501.

Kurmanov, N., Kabdullina, G., Karbetova, Z., Tuzubekova, M., Doshan, A., \& Karbetova, S. (2013). Motivation of Employees' Labor Activity in Oil and Gas Companies in Kazakhstan. World Applied Sciences Journal, 26(12), 1556-1561.

Matthews, R. (2003). New Matrix, or logic of strategic advantage. Moscow: Olma-Press, Institute of Economic Strategies.

Michailova, S., \& Liuhto, K. (2001). Organization and management research in transition economies: towards improved research methodologies. Journal of East-West Business, 6(3), 7-46.

Mintzberg, H., \& Gosling J. (2002). Reality Programming for MBAs. Strategy and Business, 26(1), $28-31$.

Mukhamedzhanov, B. G., \& Abdirayymova, G. S. (2011). The higher education in Kazakhstan: social practicians, subject’s interests. Scientific edition. The monograph. Almaty: Private Fund «Fund of the First President of the Republic of Kazakhstan».

Piven, G., \& Pak, I. U. (2006). Higher education in Kazakhstan and the Bologna Process. Russian Education \& Society, 48(10), 82-91.

Rumyantseva, N. L. (2004). Higher education in Kazakhstan: The issue of corruption. International Higher Education, 37, 24-25.

Schmidt, P. (2008). As Wall Street Shudders, business schools rethink curricula. Chronicle of Higher Education, 55(6), 2937.

The Agency of Statistics of the Republic of Kazakhstan. Retrieved from http://www.stat.kz/digital/obraz/Pages/default.aspx 
CBU I NTERNATI ONAL CONFERENCE ON I NNOVATION, TECHNOLOGY TRANSFER AND EDUCATION

The Ministry of Education and Science of the Republic of Kazakhstan (2010). State program of education development in the Republic of Kazakhstan for 2011-2020, approved by decree of the President of the Republic of Kazakhstan, No. 1118. (2010, December 7). Retrieved from http://akorda.kz/upload/SPED.doc

Turekulova, D. M., Kurmanov, N. A., \& Zhumanova, B. K. (2013). Development strategy of business. International journal of applied and fundamental research. Retrieved from http://www.science-sd.com/452-24346

Zhuplev, A. V., \& Kozhakhtnetov, A. B. (1997). Business Education in Kazakhstan: Ramifications under Transition. Journal of East-West Business, 3(3), 67-89. 